\title{
SOCIO-ECONOMIC STATUS OF WOMEN - A CASE STUDY
}

\author{
Sarat Kumar Nath, \\ Assistant professor (Ad-hoc), Dept. Of Economics, Charaibahi College \\ Biswajit Nath, \\ PhD Research Scholar, Gauhati University
}

\begin{abstract}
Women play a key role in supporting their household and communities, in achieving food and nutrition security, generating income and improving livelihood and overall well-being of the society. If women get access to land leadership, opportunities and choices economies grow, food security is enhanced and prospects are improved for both current generation and future generations. But gender discrimination is a real phenomenon in India. Women in rural area do not having proper facilities and education for their development. Most of the rural women have less access to healthcare, education and other aspects of the society. This paper studies the status of women in the field of education, income and employment. 15 villages of Morigaon Revenue Circle (Morigaon district) are purposively selected by the author for this study.
\end{abstract}

Key Words: Nutrition security, Gender discrimination, Healthcare.

\section{Introduction :}

Removal of 'Gender Inequality' is important for both intrinsic and instrumental reason. If affects social harmony and social well being in various dimensions. Education, poverty, labor market, financial market, political and economic empowerment, economic development etc. are being affected by the gender inequality. Moreover, less gender disparity enhances prospects for various national and international goals like Millennium Development Goals (MDGs), Education for all, Convention on education of all forms of discrimination against women (CADAW), Vision 2030, Economic Recovery and employment creation Strategy etc. 'Gender Inequality' in any time and any where undermines the economic growth and economic development by retarding a section of the society from the access of education, employment and other social issues. It is particularly true in the Less Developed Countries (LDCs) where women have after less access to education, employment, financial and other social services.

\section{Objectives of the paper:}

Socio economics status of women explain the nature of gender disparity in the society. Author set the following objectives while writing the paper -

a) To measure the contribution of women in productive activities. The questions answered under this head are :

- What are the rates of labor force participation and work force participation for male and female in the study area?

- Is there any significant difference between the rates?

- What is the nature of employment in the study area?

b) To investigate the level of education of men and women in the study area. The questions answered under this head are :

- Is there only significant difference between the literacy rates of male and female in the study area?

- What is the nature of educational attainment in the area?

c) To examine the average income of male and female in the study area under this head of the following questions are answered :

- Is there any disparity between male and female median income in the area?

- Is there any disparity of income in organized sector and unorganized sector? 


\section{Study area :}

The study area is Morigaon Revenue Circle. Fifteen villages of Morigaon Revenue Circle are purposively selected by the author. These villages are- Auguri, Latimari Nigam, Udari, Sidhabari, Solmari, Konwargaon, Mikirgaon, Patidaya, Domal, Borigaon, Naukata, Bhurbandha, Morikolong and Bagharagaon. Survey was conducted to cover 150 households. Almost 495 people were covered by the case study.

\section{Research Methodology :}

Both analytical and descriptive methods are used in the study. Study is based on primary as well as secondary data. For secondary data author used NSS reports, reports from newspaper, statistical hand book etc. For primary data a case study was done by using appropriate schedules. Author selected the villages randomly.

\subsection{Nature of employment and various statistics :}

The employment status of women in household is being viewed as a symbol of status in the society. Women who contribute monetarily are perceived as indispensible member of family, in fact of the society. To measure the status of women in the study area Labour Force Participation Rate (LFPR) and Work force Participation Rate (WPR) are used.

\subsubsection{Labour Force Participation Rate :}

LFPR is the percentage of people (male \& female) who are willing to engage in productive activities. Symbolically-

LFPR $=\frac{\text { No. of persons willing to work }}{\text { Total population }} \times 100$

Here no. of persons willing to work implies both employed and unemployed persons.

\begin{tabular}{|c|c|c|c|}
\hline Area & Male & Female & Overall \\
\hline India & 55.69 & 22.81 & 39.73 \\
\hline Assam & 56.97 & 17.67 & 37.8 \\
\hline Sample area & 71.62 & 60.08 & 69.4 \\
\hline
\end{tabular}

Source : NSS $66^{\text {th }}$ report and sample

Table 1 : Labour force Participation Rate

Observation :

- LFPR for both male and female in the study area are higher than that of Assam \& India.

- LFPR for men is significant higher than that of female in the study area.

\subsubsection{Work force Participation Rate (WPR):}

WPR is the percentage of people who are currently in the work force. Symbolically

WPR $\quad=$ No. of employed person $\times 100$

Total population

The following table reveals the scenario of WPR in the study area :

\begin{tabular}{|c|c|c|c|}
\hline Area & Male & Female & Overall \\
\hline India & 54.58 & 22.2 & 38.9 \\
\hline Assam & 54.95 & 14.89 & 35.3 \\
\hline Sample area & 63.29 & 51.13 & 57.7 \\
\hline & \multicolumn{3}{|l}{} \\
\hline
\end{tabular}

Source : NSS $66^{\text {th }}$ report and sample

Table 2: Work force Participation Rate 


\section{Observation :}

- WPR for both male and female are higher in the study area than India \& Assam.

- WPR is higher for male as compared to the female in the study area.

\subsection{Sectoral distribution of employment :}

Sectors are majorly divided into three parts- primary, secondary and tertiary sectors. Basing on employment condition these are further classified into organized and unorganized sector. The organized sector is one that is incorporated with appropriate authority or government it follows the rules and regulations. On the contrary, unorganized sector is not incorporated with the government, where no rules are followed. Organized sector is more secured than unorganized sector. The following table reveals engagement of male and female across organized and unorganized sector.

\begin{tabular}{|c|c|c|c|}
\hline Area & & Organized Sector & Unorganized sector \\
\hline \multirow{2}{*}{ Study Area } & Male & $11.24 \%$ & $88.76 \%$ \\
\cline { 2 - 4 } & Female & $9.4 \%$ & $90.6 \%$ \\
\hline \multirow{2}{*}{ Assam } & Male & $8.63 \%$ & $91.32 \%$ \\
\cline { 2 - 4 } & Female & $4.51 \%$ & $83.59 \%$ \\
\hline
\end{tabular}

Source : NSS $66^{\text {th }}$ report and sample

Table 3 : Sector distribution of workforce.

\section{Observations :}

- More male and female are engaged in organized sector in study area than that of Assam

- More male are engaged in organized sector than female in the sample area i.e. less female are getting secured job.

\subsection{Nature of Work:}

Nature of work implies the nature of employment . Various types of employment were found in the study area. The following table represents the nature of the work and their engagement percentage.

\begin{tabular}{|l|c|c|}
\hline \multicolumn{1}{|c|}{ Work } & \% of female engagement & $\begin{array}{c}\% \text { of male } \\
\text { engagement }\end{array}$ \\
\hline Regular salaried & $9.4 \%$ & $11.24 \%$ \\
\hline Casual labour & $11.11 \%$ & $4.73 \%$ \\
\hline $\begin{array}{l}\text { Spinning, tailoring \& } \\
\text { weaving }\end{array}$ & $32.47 \%$ & $1.77 \%$ \\
\hline Paid domestic worker & $7.69 \%$ & $20.71 \%$ \\
\hline Self employed in agriculture & $3.4 \%$ & $41.42 \%$ \\
\hline Agricultural labour & $23.07 \%$ & $14.79 \%$ \\
\hline Others & $12.82 \%$ & $5.32 \%$ \\
\hline
\end{tabular}

Source : Sample Survey

Table 4 : Nature of work

From the above table, it is obvious that, even in unorganized sector women engagement is high in case of low paid jobs. In the study area casual labour, spinning, tailoring \& weaving, agricultural labor are low paid job.

\section{Educational Attainment :}

Education is the panacea of all social evils. A well educated person always understand the society better and hence can act for the betterment for the society. Therefore we may say that higher the literacy less is the crime in the society. But literate person should be actually literate, which do not mean the reading, writing and speaking ability. He or she should be morally educated.

Education is an important indicator of socio economic status. Median earning increase with each level of education. Higher level of education is associated better economic and psychological 
outcomes, i.e. more income, more control, greater support and networking etc. Moreover, education can make a person more aware of the social values and responsibilities. Educated individuals are of higher social status as they can carry out various social duties effectively.

To examine the educational status of women literacy rate of male and female are computed. Literacy rate of study area is $72.8 \%$ which nominally higher than the state average $(72.19 \%$ in 2001$)$. Moreover, there is gender disparity in the study area in case of literacy rate. Literacy rate for male is $78.2 \%$ which is quite higher that of female $(67.41 \%)$

The following table (table 5) gives the attainment of education for male and female in the study area :

\begin{tabular}{|c|c|c|}
\hline Highest attainment level & Male & Female \\
\hline Lower primary & $32.05 \%$ & $45 \%$ \\
\hline Upper primary & $15.78 \%$ & $19.4 \%$ \\
\hline High School & $19.13 \%$ & $10.38 \%$ \\
\hline High Secondary & $23.44 \%$ & $18.83 \%$ \\
\hline Graduate & $6.22 \%$ & $4.5 \%$ \\
\hline Post graduate & $3.34 \%$ & $1.29 \%$ \\
\hline
\end{tabular}

Source : Sample Survey

Table 5 : Highest educational attainment of educated persons.

Observation :

- $32.05 \%$ of male have LP education as their highest qualification which is $45 \%$ for female.

- $15.78 \%$ of literate male have UP education as highest qualification which it is $19.4 \%$ for female.

- $19.13 \%$ of male have high school education as highest qualification while this rate is $10.38 \%$ for female.

- $23.44 \%$ of educated male have higher secondary level as their highest attainment, while this rate is $18.33 \%$ for female.

- $6.22 \%$ of educated male and $4.5 \%$ of female attained graduate degree.

- $3.34 \%$ of male and $1.29 \%$ of female attained Post graduate degree.

Thus, in the study area, it is seen that in case of educational attainment male are in better state than female. It is evident in percentage also in units.

\section{Income Distribution :}

Income refers to wages, salaries, profit, rents and any flow of earnings received. It is not the absolute income but the relative income determines socio-economic status. To examine the relatives income of female, median income of male and female in both organized and unorganized sector are compared.

\begin{tabular}{|l|l|l|}
\hline & Organised sector & Unorganised sector \\
\hline Male & 30210.20 & 10133.3 \\
\hline Female & 26545.15 & 8324.57 \\
\hline
\end{tabular}

Source : Sample survey

Table 6 : Mean salary across sectors

Observation :

- Mean salary in the organized sector is higher than the unorganized sector for both male and female. The overall salary is Rs. 28866.6 in organized sector which is 3 time of the salary in unorganized sector.

- Male in organized sector have higher salary (Rs. 30210) than the female (Rs. 26545.15)

- Average salary of male in unorganized sector is higher than that of female.

Thus, women are behind men in case of average earning too. 


\section{Conclusion :}

To conclude we may say that the status of women in the study area is not same as men in case of employment, income and educational attainment. Policy intervention towards removing barriers to general female well being include economic and knowledge empowerment, increasing access to financial services, employment and participation in decision making. Awareness programmes will require for transformation of mindset within govt. decision makers, boy and girls, men and even women themselves on the gender consequences of policies in the country. A more wholesome approach based on genuine political willingness, involvement of religious, media, family unit, private sector agencies and civil societies in intense action is required to remove such disparity.

\section{References :}

1) Sample Survey conducted between $1 / 9 / 19$ and $15 / 9 / 19$

2) NSS $66^{\text {th }}$ report.

3) Statistical Hand book of Assam, 2016

4) News Paper report.

5) Women and men in India, A statistical complication of gender related indicators in India, $\mathrm{CSO}$

6) Measuring the socio-economic status of women across the life course, Jennifer Baster and Mathew Taylor. 